\title{
Kizphonic as digital multimedia online to enhance vocabulary of young learners
}

\author{
${ }^{1}$ Lilies Youlia Friatin* and ${ }^{2}$ Widiyaningsih \\ 1,2 Faculty of Teacher Training and \\ Educational Sciences of Galuh University \\ *Corresponding author \\ Email: lilies.youlia@yahoo.co.id
}

\begin{abstract}
This study investigates the implementation of Kizphonic to enhance the vocabulary of young learners learning English as a foreign language in one of Elementary School in Ciamis, West Java. The participants in this research are all of students of the the fourth grade in one state Elementary School in Ciamis. The problem of this study is the students of the fourth grade Elementary School still in a poor of vocabulary. The aims of this study are to find out how the effect of use Kizphonic online program to enhance vocabulary of young learners and to find out students' perceptions toward the use of Kizphonic online program during the learning process. The present study employs mixed - method study. Two instruments used in this study are observation and questionnaire. The result of the first instrument, Kizphonic as digital multimedia has a big chance on the implementation to support teachers and students in learning process, especially to enhance their vocabulary. The second instrument revealed that the majority of the students viewed that the use of Kizphonic was effective, motivating and interesting digital multimedia. It made students remember vocabulary more easily. It can be concluded that Kizphonic is able to enhance students' motivation and enhance students' English vocabulary.
\end{abstract}

Keywords: Multimedia, Vocabulary, Young Learners, Kizphonic

Received:

Revised:

Accepted:

Published:

30 December 201720 July 2018

30 August 2018

31 August 2018

\section{INTRODUCTION}

The success of learning a foreign language is assumed in term of the ability to communicate by using English. Therefore students should able to have enough vocabulary. Vocabulary is increasingly as a crucial component to language learning. The teaching vocabulary for children as beginner in learning a language is very important. In learning a foreign language, vocabulary plays an important role. It is one element that links the four skills of speaking, listening, reading and writing all together. In order to communicate well in a foreign language, students should acquire an adequate number of words and should know how to use them accurately. According to Piaget's theory cited in Wadsworth (2004) a child at the age of 7-10 years is 
always interesting in recognizing and knowing new words, he stands to redundant so that he will memorize them.

Technology in language teaching is not new these days. It has been around in language teaching for decades. The use of Information and Communications Technology (ICT) by language teachers such as multimedia technology, audiovisual, software and internet access materials have greatly improved and made the use of these resources in the classroom more practical. According to Cutting ( 2011, p. 4 ) multimedia is a relatively new word that is used to describe a combination of different media, all being used to best describe or explain something, sometimes referred to as "audio-visual aids", to help in our teaching. The use of audiovisual in the classroom is important because of the flexibility in presenting the lessons. It adds the context to the language and the lesson. Furthermore, the use of audiovisual helps students and teacher to connect vocabulary meaning and make the lesson more interesting because of the motion, colour and sound in ways that can dramatize the ideas better than any other medium.

In fact, after conducting question and answer to the English teacher's opinion in SDN 4 Buniseuri Ciamis, the writers concluded there are some problems in mastering English vocabulary. First, the students' vocabulary is still poor. The second, their spelling is also poor. Third, their capability of the concept of meaning is not so bad, but sometimes, they are still confused to the word that its object is closed, such as wall and ceiling. It can be proved, when the teacher pointed the 'wall' picture, some students mentioned 'ceiling'. In contrary, when the teacher pointed 'ceiling' picture, they mentioned 'wall'. In addition, Anwar (2016) says, most of students of Elementary School have minimum motivation to speak English because the English materials themselves have not been taught in pleasant and interesting ways. It means that the students need attractive technique in learning English to achieve their learning goal. One of the alternative techniques that can be used in teaching English vocabulary to young learners is using multimedia. According to Andersen and Brink (2013), multimedia offers a variety of media usually combined in a meaningful manner. This gives an opportunity to use the computer for teaching process in different ways, including by: Images, or scanned photographs, drawings, maps, slides, sounds, music and video. Hence, the writers were interested in using multimedia especially digital multimedia online to enhance the students' vocabulary and in this research the teacher tried to apply Kizphonic as a media in teaching vocabulary.

To emphasize, the study conducted by Arono (2014) entitled "Improving Students Listening Skill through Interactive Multimedia in Indonesia" showed that the use of interactive multimedia can improve students' critical listening skill ability. Another study by Ali (2014) stated that some applications of computer- based technology in the foreign language classroom, such as Digital Stories, Computer Games, Moving Pictures and Digital Songs, if appropriately selected and organized can play a significant role in enhancing young learners' learning abilities, especially vocabulary learning supporting the fact that the initial stages of foreign language teaching should be devoted "almost entirely to vocabulary development" (Cameron, 2005, p. 77). However, all of previous studies focus on the impact of using interactive multimedia and digital stories, without investigating student's perception. Furthermore, this study fills the 
gap by investigating the issue on the implementation of Kizphonic as digital multimedia online to enhance vocabulary of young learners.

\section{Digital multimedia}

Digital multimedia is derivative from digital and multimedia. This is a result from quick progress of the present technology. Equipment which is resulted from digital and multimedia is computer. Computer is description from digital which process letter and numeral and multimedia present picture, voice, video, etc. According to Cutting (2011) multimedia is a relatively new word that is used to describe a combination of different media, all being used to best describe or explain something, sometimes referred to as "audio-visual aids", to help in our teaching. Multimedia presents picture, voice, video, etc. Cutting stated on his book (2011) that when all the things that we want to use are converted into a digital format, and then we call it digital multimedia.

Vaughan (1992) said that multimedia is any combination of text, art, sound, animation, and video delivered to you by computer or other electronic or digitally manipulated means. Agnew et.al, (1996) cited in Neo (2001, p. 20) Multimedia defined the combination of various digital media types such as text, images, sound and video, into an integrated multi-sensory interactive application or presentation to convey a message or information to an audience. In other words, multimedia means an individual or a small group using a computer to interact with information that is represented in several media, by repeatedly selecting what to see and hear next. Besides, according to Margaret (2005) http://whatis.techtarget.com/definition/digital digital describes electronic technology that generates, stores, and processes data. Equipment which is resulted from new digital age is computers and the Internet. Computer is description from digital which process letter and numeral. Digital Multimedia has a very simple definition. It is two important elements that have been made possible by the combination of computers, software, and networks.

\section{An overview of vocabulary}

Language is an important thing for human life. Without language, human in the world cannot communicate and interact with each other. In addition, language is also distinguishing factor for groups of human beings. Language becomes more functional for us if our language skills improve. Improving our language skill is depending on some important aspects of language. And one of them is vocabulary. Vocabulary is one of language elements that should be mastered by the students to increase their English mastery.

According to Linse and Nunan (2005), vocabulary is the collection of words that an individual knows. In this study means that vocabulary is a sentence or characters that have one or more meaning. In other hand, Richard and Renandya (2002) define vocabulary as one component of language proficiency and provides much of the basis for how well learners listen, speak, read and write. It can be said that vocabulary is a basic of the language and fundamental in speaking, listening, reading and writing. 
Furthermore, Pikulski and Templeton (2004), vocabulary can be diagrammed into the figure below:

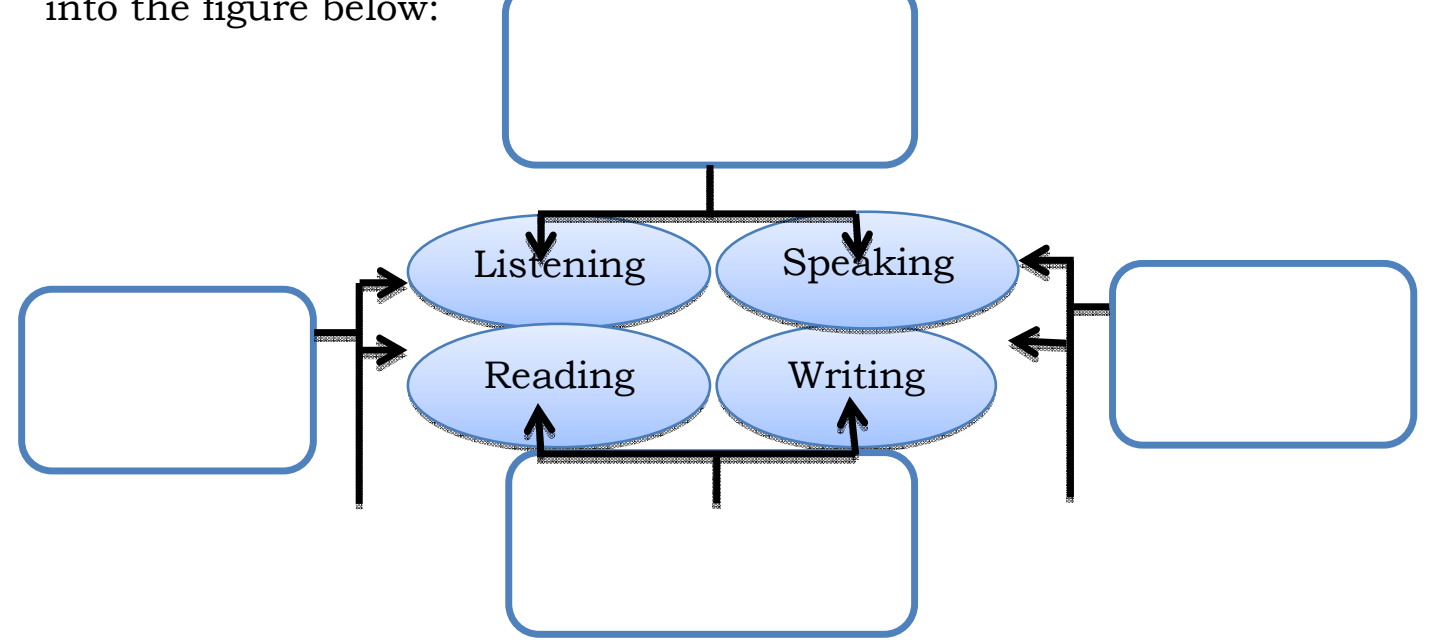

Figure 1. The relationship of the eight different terms

From the figure 1 above, we can take some information. Firstly, the term expressive vocabulary is used to refer to speaking and writing since these are the vocabularies we use to express ourselves. And then, the term receptive vocabulary is used to refer to listening and reading vocabularies. Finally, to round out the terminology, meaning or oral vocabulary refers to the combination of listening and speaking vocabularies, and literate vocabulary refers to the combination of our reading and writing vocabularies. Based on the opinion above, the researcher views vocabulary as a number of words used means of communication and it can be conclude that vocabulary is a word to communicate the language and used by the students and the teachers in teaching and learning process.

\section{The nature of young learners}

Philips (2003, p. 3) defined young learners as "children from the first years of formal schooling (five or six years old) to eleventh or twelve years of age". From that theory it can be said that young learners are the students who have enough age to go to study.

Young learner is "children are at preschool or in the first couple of years of schooling" (Pinter, 2006, p. 2). Meanwhile, according to Scott and Ytreberg (2001), there are some characteristic of young language learners:

a. They know that the world is governed by rules. They may not always understand the rules, but they know that they are there to be obeyed, and the rules help to nurture a feeling of security. It means that young learners always make a new rule and try to find out the solution about the problem by themselves.

b. They understand situation more quickly than they understand the language used. It means that young learners understand situation more quickly than language in use because they are easily 
learn/understand something by watching and touching around them.

c. They use language skills long before they are aware of them. It means that young learners could speak and listening before they learns vocabularies.

d. Their own understanding comes through hands and eyes and ears. It means that more effective if teaching English vocabulary to young learners by touching and watching the things because they can more understand.

e. They are very logical. What you say first happen first. Ex: before you turn off the light, put your book away", can mean I turn off the light and then 2 put your book away.

f. They have a very short attention and concentration span. It means that young learners have their own word. As a teacher, we should prepare all of things before we begin teach them such as various method, activity or media to make them more fun and enjoy while teaching and learning process.

g. Young children sometimes have difficulty in knowing what fact is and what fiction is. Young learners have very little knowledge. They need someone to explain more deeply what is fact and fiction.

h. Young children are often happy, playing and working alone but in the company of others. It means teaching young learners have to use a media that make them happy, so that they can play and let them working alone.

The researcher agrees with him. Young learners have different characteristic from each other. That thing makes young learners unique. It makes the researcher should prepare all of things before the teacher begin teach them such as varied activity, method, etc.

\section{Kizphonics in teaching vocabulary}

This is a kind of software that can be used in teaching vocabulary. The form of this software offers work for the teacher, games, videos, power-point, and flash cards. The researcher opened it from http://www.Kizphonics.com In this application, children will learn to distinguish between the uppercase and lowercase letters of the alphabet while learning the beginning sounds of letters and three new words beginning with each letter. This is the first step in learning to read. Children will learn phonemic and kind of vocabularies in these activities.

After learning different materials in Kizphonic, they will be able to:

\section{Understand everyday language}

Through Kizphonic proficiency-based speaking, listening, writing and reading activities, they'll learn quickly. It has good effect for the students who used Kizphonics. It can improve their vocabularies as their basic in speaking, listening, writing and listening. Beside that they also can understand use the vocabularies in everyday language through watching short story in video.

2. Pronounce word correctly.

After practicing Kizphonic flashcard, video and game, pronunciation will come easily. Some material in Kizphonics program such as: flashcard, video and 
game are helping student in learning vocabularies especially pronounce each word correctly.

3. Spell and write accurately

They'll build gradually from letters to words and sentences. Kizphonics was application to distinguish between the uppercase and lowercase letters of the alphabet while learning the beginning sounds of letters and three new words beginning with each letter. It means Kizphonics is one of good application media to improve their spelling and writing.

4. Engage in real-life conversation

With different kind of videos, learners will gain confidence using speech alone in simulated situations. Students will use the different kind of vocabularies that they have learnt in Kizphonics and practiced it in real-life.

\section{METHOD}

Related to the aim of the study, this study employed mixed approaches study i.e. the combination of a qualitative and quantitative component in a single research project (Bergman, 2008). Quantitative and qualitative approach as it involved the data collection and data analysis. Hence the population of this research were all students of SDN 4 Buniseuri. In this research, the researcher takes sample from the population of the research, students of the fourth grade of SDN 4 Buniseuri Ciamis consisting of 25 students as the sample. The first instrument was used observation to collect the data. The second instrument was questionnaire.

\section{Data Analysis Technique}

In analyzing the results of classroom observation data, the researcher classified, interpreted, and commented all the data classroom observation documents based on the data from video record. Direct questionnaire was used which means the statements had been ordered before. The students were asked to answer six statements in the form of questionnaire consisting of five options each. The writers gave the students 45 minutes to fill questionnaire. In measuring each item of the questionnaire, the writers measured it by using Likert Scale (Dornyei, 2003), and it ordered five responses levels. They are as follows:

1. Strongly disagree

2. Disagree

3. Neutral

4. Agree

5. Strongly agree

From the theory above, Likert Scale was used as guide to measure questionnaire.

To analyze the result from questionnaire, the researchers classified the data into. Those answers are presented in the form of frequency observed. After the writers calculated the frequency of each option, then the teacher 
computed it into percentage calculation as suggested by Hatch and Farhady ( 1982, p. 43 ) as follows :

$$
p=\frac{F o}{n} \times 100 \%
$$

Notes:

$\mathrm{P}$

Fo

$\mathrm{N}$
$=$ percentage of each category

$=$ frequency observed

$=$ the number of sample

The writers also used some percentage categories in order to interpret the data obtained. They are:

$0 \%=$ none of respondents choose this alternative

$1 \%-25 \%=$ a small part of the respondents choose this alternative

50

$50 \%$

51

$76 \%-99 \%$

100

$-49 \%=$ almost half of respondents choose this alternative

$=$ half of the respondents choose this alternative

$-75 \%=$ most of the respondents choose this alternative

$=$ almost all of the respondents choose this alternative

$=$ all of the respondents choose this alternative

\section{RESULTS AND DISCUSSION}

Regarding the research questions, the researcher found some relevant data from classroom observation and questionnaire. The researcher found the data to answer the research questions on "How is the effect of use Kizphonic online program to enhance vocabulary of young learners" and "What are students' perceptions toward the use of Kizphonic online program during the learning process". Moreover, the data analysis presented from each research questions. The first one was data from the first research question on the effect of use Kizphonic online program to enhance vocabulary of young learners that has been collected through classroom observation and the second one was the data from the students' opinion on the use of Kizphonic online program during the learning process that has been collected through the questionnaire.

Related to the first research question, it was found that effect of use Kizphonic online program to enhance vocabulary of young learners. In the first observation, it was conducted on Tuesday, January $24^{\text {th }} 2017$, at 11.00 a.m 12.10 p.m in SDN 4 Buniseuri. Teacher stimulated the students by showing them and giving them new vocabulary about kinds of animal in Kizphonic. The students answered the questions enthusiastically. Then, taught them kind of vocabularies begin with the letter A to F and sound "ai" such as "train, rain, brain, nail, snail, and tail. The teacher pointed the picture and taught them the way to read. After, the students listened the way to read, the teacher gave opportunity to them to try read properly in front of the class. In the end of the class the teacher made a conclusion and gave them homework.

The second observation was conducted on Wednesday, January $25^{\text {th }}$ 2017 , at 11.00 a.m - 12.10 p.m. In the second observation, the teacher showed the video as stimulation. After the teacher turned on more than twice, the teacher let the student to observe which one the strange words and ask 
the students to write all the sentences by finding the meaning. The teacher let the students to demonstrate it in front of the class. While the students demonstrate it, the teacher paid attention to their pronunciation and corrected any wrong pronunciation. In the end of the class, the teacher ask them some questions about last material such as "what animal begin with letter A?" All of the students were given different answer loudly.

The last observation was conducted on Thursday, January $26^{\text {th }}$ at 11.00a.m - 12.10p.m 2017. The teacher shows flashcard as stimulation. When the teacher began to open the flashcard in Kizphonic the students began noisy and shouting to say "jas hujan , sepatu boat, palu, bulan". Then, the teacher read vocabulary with proper pronunciation, the teacher asked the students to follow the pronunciation after her. In the end of the class the teacher asked the students to create a dialog by using the vocabulary in flashcard. The teacher gave students the opportunity to practice in pairs in front of the class. Then, the teacher did some assessment activities by asking them the meaning of it. Before the time was over, the teacher gave some questionnaire to them and asked them to answer it. In closing activity the teacher said that the teacher thanked to the students for their attention. Based on the observation, it can be concluded that Kizphonic as digital multimedia has a big chance on the implementation to support teachers and students in learning process, especially to enhance their vocabulary. In line with this, Cutting (2011) says that multimedia is a relatively new word that is used to describe a combination of different media, all being used to best describe or explain something, sometimes referred to as "audio-visual aids", to help in our teaching. It means that digital multimedia was the best media to describe or explain something to help teacher in teaching and learning process.

Meanwhile, related to the second research question, the researcher collected the data using a brief rating scales questionnaire (Strongly Agree, Agree, Neutral, Disagree or Strongly Disagree) to ask some questions related with students' perception toward the use of Kizphonic online program during the learning process. Responses of the questionnaire item from 25 respondents (sample) the data of the study. Description of the data can be seen in following table.

Table 2. Responses of the Questionnaire Items

\begin{tabular}{|c|c|c|c|c|c|c|c|}
\hline \multirow{2}{*}{ No. } & \multirow{2}{*}{ Statements } & \multicolumn{5}{|c|}{ Response } & \multirow{2}{*}{ Total } \\
\hline & & SA & $\overline{\mathbf{A}}$ & $\mathbf{N}$ & D & SD & \\
\hline 1 & $\begin{array}{l}\text { I like learning English } \\
\text { vocabulary using Kizphonic }\end{array}$ & 25 & 0 & 0 & 0 & 0 & 25 \\
\hline 2 & $\begin{array}{l}\text { Kizphonic motivated me to } \\
\text { learn English }\end{array}$ & 25 & 0 & 0 & 0 & 0 & 25 \\
\hline
\end{tabular}


EduLite Journal of English Education, Literature, and Culture

\begin{tabular}{|c|c|c|c|c|c|c|c|}
\hline 3 & $\begin{array}{l}\text { I can understand the } \\
\text { material being taught by } \\
\text { teacher using Kizphonic }\end{array}$ & 24 & 1 & 0 & 0 & 0 & 25 \\
\hline 4 & $\begin{array}{l}\text { Kizphonic make me } \\
\text { interested in jointing the } \\
\text { lesson from begining to the } \\
\text { end }\end{array}$ & 25 & 0 & 0 & 0 & 0 & 25 \\
\hline 5 & $\begin{array}{l}\text { Kizphonic help me } \\
\text { remember the vocabulary. }\end{array}$ & 23 & 2 & 0 & 0 & 0 & 25 \\
\hline 6 & $\begin{array}{l}\text { I can easily remember the } \\
\text { vocabulary } \\
\text { Kizphonic. }\end{array}$ & 20 & 5 & 0 & 0 & 0 & 25 \\
\hline 7 & $\begin{array}{l}\text { I can feel a new suasana of } \\
\text { learning English vocabulary }\end{array}$ & 25 & 0 & 0 & 0 & 0 & 25 \\
\hline 8 & 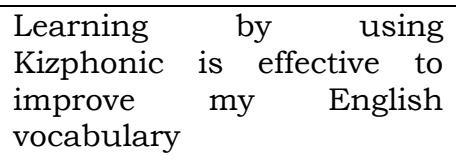 & 25 & 0 & 0 & 0 & 0 & 25 \\
\hline
\end{tabular}

Note: SA (Strongly Agree), A (Agree), N (Neutral), D (Disagree), SD (Strongly Disagree).

To find the results of the study, the researcher analyzed obtained data in table 2. In analyzing the data, the researcher calculates the percentage computation. The formula of the computation is as follows:

\section{Number of Frequency}

$$
\text { Total }
$$

Table 3 Responses of the Questionnaire Items (\%)

\begin{tabular}{|c|c|c|c|c|c|c|c|}
\hline \multirow{2}{*}{ No. } & \multirow{2}{*}{ Statements } & \multicolumn{5}{|c|}{ Response } & \multirow{2}{*}{ Total } \\
\hline & & SA & $\mathbf{A}$ & $\mathbf{N}$ & D & SD & \\
\hline 1 & $\begin{array}{lr}\text { I like learning } & \text { English } \\
\text { vocabulary } & \text { using } \\
\text { Kizphonic } & \end{array}$ & $100 \%$ & $0 \%$ & $0 \%$ & $0 \%$ & $0 \%$ & $100 \%$ \\
\hline 2 & $\begin{array}{l}\text { Kizphonic motivated me } \\
\text { to learn English }\end{array}$ & $100 \%$ & $0 \%$ & $0 \%$ & $0 \%$ & $0 \%$ & $100 \%$ \\
\hline
\end{tabular}




\begin{tabular}{|c|c|c|c|c|c|c|c|}
\hline 3 & $\begin{array}{l}\text { I can understand the } \\
\text { material being taught by } \\
\text { teacher using Kizphonic }\end{array}$ & $96 \%$ & $4 \%$ & $0 \%$ & $0 \%$ & $0 \%$ & $100 \%$ \\
\hline 4 & $\begin{array}{l}\text { Kizphonic make me } \\
\text { interested in jointing the } \\
\text { lesson from begining to } \\
\text { the end }\end{array}$ & $100 \%$ & $0 \%$ & $0 \%$ & $0 \%$ & $0 \%$ & $100 \%$ \\
\hline 5 & $\begin{array}{lll}\text { Kizphonic } & \text { help } & \text { me } \\
\text { remember } & & \text { the } \\
\text { vocabulary. } & & \end{array}$ & $92 \%$ & $8 \%$ & $0 \%$ & $0 \%$ & $0 \%$ & $100 \%$ \\
\hline 6 & $\begin{array}{l}\text { I can easily remember } \\
\text { the vocabulary using } \\
\text { Kizphonic. }\end{array}$ & $80 \%$ & $20 \%$ & $0 \%$ & $0 \%$ & $0 \%$ & $100 \%$ \\
\hline 7 & $\begin{array}{l}\text { I can feel a new situation } \\
\text { of learning English } \\
\text { vocabulary }\end{array}$ & $100 \%$ & $0 \%$ & $0 \%$ & $0 \%$ & $0 \%$ & $100 \%$ \\
\hline 8 & $\begin{array}{l}\text { Learning by using } \\
\text { Kizphonic is effective to } \\
\text { improve my English } \\
\text { vocabulary }\end{array}$ & $100 \%$ & 0\% & 0\% & 0\% & $0 \%$ & $100 \%$ \\
\hline
\end{tabular}

To find out the percentace of each response to each questionnaire item, the researcher tabulated the percentage of each response and describes its interpretation to all questionnaire items in several table separately as follows:

Table 4. Response to the questionnaire number $1 \& 2$

\begin{tabular}{|c|c|c|c|c|c|c|c|}
\hline \multirow{2}{*}{ No. } & \multirow{2}{*}{ Statements } & \multicolumn{5}{|c|}{ Response } & \multirow{2}{*}{ Total } \\
\hline & & SA & $\mathbf{A}$ & $\mathbf{N}$ & D & SD & \\
\hline \multirow{2}{*}{1} & \multirow{2}{*}{$\begin{array}{l}\text { I like learning English } \\
\text { vocabulary using } \\
\text { Kizphonic }\end{array}$} & 25 & 0 & 0 & 0 & 0 & 25 \\
\hline & & $100 \%$ & $0 \%$ & $0 \%$ & $0 \%$ & $0 \%$ & $100 \%$ \\
\hline \multirow{2}{*}{2} & $\begin{array}{l}\text { Kizphonic motivated me } \\
\text { to learn English }\end{array}$ & 25 & 0 & 0 & 0 & 0 & 25 \\
\hline & & $100 \%$ & $0 \%$ & $0 \%$ & $0 \%$ & $0 \%$ & $100 \%$ \\
\hline
\end{tabular}

Based on the first and the second statements in the table 4, it was found the result that 25 students or $100 \%$ categorized as all of the respondents expressed on the agreement that they strongly agree with learning English vocabulary using Kizphonic. . It means that all of the respondents like and motivated learning English vocabulary by using Kizphonic It can be seen from the situation of class in which the researcher was conducting observation; they enjoying learning English vocabulary and followed all of activities instructed by the researcher. 
Table 5. Response to the questionnaire number 3

\begin{tabular}{|c|c|c|c|c|c|c|c|}
\hline \multirow{2}{*}{ No. } & \multirow{2}{*}{ Statements } & \multicolumn{5}{|c|}{ Response } & \multirow{2}{*}{ Total } \\
\hline & & SA & $\mathbf{A}$ & $\mathbf{N}$ & D & SD & \\
\hline \multirow{2}{*}{3} & I can understand the & 24 & 1 & 0 & 0 & 0 & 25 \\
\hline & Kizphonic & $96 \%$ & $4 \%$ & $0 \%$ & $0 \%$ & $0 \%$ & $100 \%$ \\
\hline
\end{tabular}

Based on the table presented above the researcher found the result that 24 student or $96 \%$ categorized as almost all of the respondents who chosen strongly agree with the third statement. It means that they can understand to the material by using Kizphonic. Meanwhile, 1 student or 4\% categorized as small number of respondents chosen agree. It means that they can understand to the material by using Kizphonic.

Table 6. Response to the questionnaire number 4

\begin{tabular}{clcccccc}
\hline \multirow{2}{*}{ No. } & Statements & \multicolumn{7}{c}{ Response } & \multirow{2}{*}{ Total } \\
\cline { 3 - 6 } & $\mathbf{S A}$ & $\mathbf{A}$ & $\mathbf{N}$ & $\mathbf{D}$ & $\mathbf{S D}$ & \\
\hline \multirow{2}{*}{4} & $\begin{array}{l}\text { Kizphonic make me } \\
\text { interested in jointing the } \\
\text { lesson from beginning to } \\
\text { the end }\end{array}$ & $100 \%$ & $0 \%$ & $0 \%$ & $0 \%$ & $0 \%$ & $100 \%$
\end{tabular}

Based on the table 6 , it was found the result that 25 students or $100 \%$ categorized as all of the respondents expressed on the agreement that they strongly agree with learning English vocabulary using Kizphonic. It means that all of the respondents interested in jointing the lesson from beginning to the end by using Kizphonic It can be seen from the situation of class in which the researcher was conducting observation; they wanted to know more another vocabularies.

Table 7. Response to the questionnaire number 5

\begin{tabular}{|c|c|c|c|c|c|c|c|c|c|}
\hline \multirow{2}{*}{ No. } & \multirow{2}{*}{\multicolumn{3}{|c|}{ Statements }} & \multicolumn{5}{|c|}{ Response } & \multirow{2}{*}{ Total } \\
\hline & & & & SA & $\mathbf{A}$ & $\mathbf{N}$ & D & SD & \\
\hline \multirow{2}{*}{5} & Kizphonic & help & me & 23 & 2 & 0 & 0 & 0 & 25 \\
\hline & vocabulary. & & & $92 \%$ & $8 \%$ & $0 \%$ & $0 \%$ & $0 \%$ & $100 \%$ \\
\hline
\end{tabular}

It was found that 23 students or $92 \%$ categorized as almost all of the respondents chosen the agreements of strongly agree. It means that Kizphonic can help almost all of them to remember the vocabulary. The second agreement of agree was chosen by 2 students or $8 \%$ categorized as small 
number of respondents. It means that they support this statement that Kizphonic can help them to remember the vocabulary.

Table 8. Response to the questionnaire number 6

\begin{tabular}{|c|c|c|c|c|c|c|c|c|c|}
\hline \multirow{2}{*}{ No. } & \multirow{2}{*}{\multicolumn{3}{|c|}{ Statements }} & \multicolumn{5}{|c|}{ Response } & \multirow{2}{*}{ Total } \\
\hline & & & & SA & $\mathbf{A}$ & $\mathbf{N}$ & D & SD & \\
\hline \multirow[b]{2}{*}{6} & \multirow{2}{*}{$\begin{array}{l}\text { Kizphonic } \\
\text { remember } \\
\text { vocabulary. }\end{array}$} & \multirow[t]{2}{*}{ help } & \multirow{2}{*}{$\begin{array}{l}\text { me } \\
\text { the }\end{array}$} & 20 & 5 & 0 & 0 & 0 & 25 \\
\hline & & & & $80 \%$ & $20 \%$ & $0 \%$ & $0 \%$ & $0 \%$ & $100 \%$ \\
\hline
\end{tabular}

It was found that 20 students or $80 \%$ categorized almost all of the respondents chosen agreement of strongly agree. It means that they felt Kizphonic helped them to remember the vocabulary. Moreover, there were 5 students or $20 \%$ categorized as small number of respondents chosen agree with this statement. It means that small number of respondents of respondents that didn't feel the Kizphonic helped them to remember the vocabulary.

Table 9. Response to the questionnaire number $7 \& 8$

\begin{tabular}{|c|c|c|c|c|c|c|c|}
\hline \multirow{2}{*}{ No. } & \multirow{2}{*}{ Statements } & \multicolumn{5}{|c|}{ Response } & \multirow{2}{*}{ Total } \\
\hline & & SA & $\mathbf{A}$ & $\mathbf{N}$ & D & SD & \\
\hline \multirow[b]{2}{*}{7} & \multirow{2}{*}{$\begin{array}{l}\text { I can feel a new situation } \\
\text { of learning English } \\
\text { vocabulary }\end{array}$} & 25 & 0 & 0 & 0 & 0 & 25 \\
\hline & & $100 \%$ & $0 \%$ & $0 \%$ & $0 \%$ & $0 \%$ & $100 \%$ \\
\hline \multirow[b]{2}{*}{8} & \multirow{2}{*}{$\begin{array}{l}\text { Learning by using } \\
\text { Kizphonic is effective to } \\
\text { improve my English } \\
\text { vocabulary }\end{array}$} & 25 & 0 & 0 & 0 & 0 & 25 \\
\hline & & $100 \%$ & $0 \%$ & $0 \%$ & $0 \%$ & $0 \%$ & $100 \%$ \\
\hline
\end{tabular}

There were 25 students or $100 \%$ categorized as all of the respondents chosen strongly agree with the $7^{\text {th }}$ and $8^{\text {th }}$ statements. It means that they can felt a new situation of learning English vocabulary and effective to improve their English vocabulary. Therefore, the answer for the second research question was the students thought that the use of Kizphonic could enhance their English vocabulary and Kizphonic should be use by their teacher in class to make them more motivated in learning English.

\section{CONCLUSION}

In this research the use of Kizphonic as digital multimedia is effective in teaching vocabulary for young learners. The researcher found the result from the observation, the students felt enjoy, motivated and interested to learn English vocabulary. During three meetings, students showed their vocabulary 
development. They can understand the meaning of the word and they can pronounce the words clearly and perform perfectly.

The findings of this research is relevant with some previous studies such as Khiyabani, et al (2014), Tabar H and Khodareza M (2012), May Ali AbdulAmeer (2014), Assa'diyah T (2014), which all of the studies showed that teaching vocabulary using multimedia is effective. Based on the data analysis of questionnaire, the students thought that are use of Kizphonic could enhance their vocabulary. Most of the students had answered 'Strongly Agree' and 'Agree' to all of the statements from the questionnaire. The comparison between present study and Khiyabani, et al (2014) has the same result that using multimedia had positive effect on retention of vocabulary knowledge. The difference is this study was conducted on elementary, meanwhile Khiyabani, et al (2014) was conducted on high school. Both result of this study and Tabar $H$ and Khodareza $M$ (2012) have the same result that was using multimedia has significant impact on vocabulary learning of the learners. The difference is this study was using multimedia software "Kizphonics", meanwhile Tabar $H$ and Khodareza $M$ (2012) was using multimedia software "vocabulary".

\section{REFERENCES}

Ali, M, A. (2014). Improving Vocabulary Learning Through Digital Stories with Iraqi Young Learners of English at the Primary Level. Journal of Studies in Social Sciences, 8,197-214.

Anderesen, B.B \& Brink. (2013). Multimedia in Education. Moscow: Ves Mir Publithe teacherr.

Anwar, C. (2016). Role play and show-and-tell in grade 5 student's speaking learning. Edulite: Journal of English Education, Literature, and Culture. Vol.1, number 1, 76-102.

Arono. (2014). Improving Students Listening Skill through Interactive Multimedia in Indonesia. Journal of Language Teaching and Research, 5, 63-69.

Assa'yidah, T. (2014). The Use of Visual-aids to Improve Vocabulary Mastery on the eighth students of SMPN Kedung. Jepara: Unpublished teacher paper.

Bergman, M.M. (2008). Advances in Mixed Methods Research: Theories and Application Thousand Oaks, CA: SAGE. Google Scholar, Crossref

Cameron, L. (2005). Teaching languages to young learners. Cambridge, UK: Cambridge University Press.

Cutting, A. (2011). Using multimedia in the classroom: A guide for teachers. Samoa: Publithe teacherd by the Curriculum Materials and Assessement Division MESC.

Dornyei, Z. (2003). Questionnaires in Second Language Research. London: Lawrence Erlbaum Associates, Inc.

Futonge, K. (2012). Kizphonics. https://www.Kizphonics.com/kiz-phonicsmethodology.

Hatch, E and Farhady, H. (1982). Research Design and Statistics for Applied Linguistics. Los Angeles: Newbury House Publithe teacherrs, Inc. 
Khiyabani, H., Ghonsooly, B., \& Ghabanchi, Z.(2014). Using Multimedia in Teaching Vocabulary in High School Classes. Journal of Advances in English Language Teaching,2,1-13.

Linse, C. T. and Nunan, D. (ed). (2005). Practical English language teaching: Young learner. New York : McGraw-Hill Companies, Inc.

Margaret, P. (2005, April). Definition of Digital. Retrieved from http://whatis.techtarget.com/definition/digital.

Neo, M. (2001). Using multimedia in a problem-based learning environment. Journal of Educational \& Society, 89, 415-435.

Philips. (2003). Young learners. Oxford: Oxford University Press.

Pikulski, J., \& Templeton, S. (2004). Teaching and developing vocabulary: Key to long-term reading success. Current Research in Reading / Language $\begin{array}{lllll}\text { Arts, } & 1 & - & 12 . & \text { Retrieved }\end{array}$ http://www.eduplace.com/state/pdf/author/pik_temp.pdf.

Pinter, A. (2006). Teaching young language learners. Newyork: Oxford University press.

Richards J C, \& Renandya W A, 2002. Methodology in language teaching. Cambridge: Cambridge University Press.

Scott, W, A. and Ytreberg, L.H.(2001). Teaching English to children (4th ed). London: Longman.

Tabar, H and Khodareza, M.(2012). The effect of using multimedia on vocabulary learning of pre-intermediate and intermediate Iranian EFL learners. Journal of Basic and Applied Scientific Research.12, 1287912891.

Vaughan, T. (2004). Multimedia: Making it work. New York: McGraw Hill Technology Education.

Wadsworth, B. J. (2004). Piaget's theory of cognitive and affectivedevelopment: Foundations of constructivism. Longman Publishing. 